\title{
RESTITUTION OF UNLAWFULLY LEVIED TAXES: SURVEY AND COMPARATIVE ANALYSIS OF DEVELOPMENTS in Canada, Australia, AND ENGland
}

\section{FRÉDÉRIC BACHAND}

The common law traditionally has not been sympathetic to taxpayers wishing to recover unlawfully levied taxes from public authorities. Because a mistake of law did not, as a general rule and in itself, give rise 10 a right to restitution, and because courts refused to find that the mere fact that monies had been demanded by public authorities amounted to compulsion, taxpayers were often left without a remedy. Fortunately, important judicial developments have occurred in Canada, Australia, and England in the past decade. The demise of the infamous mistake of law rule and the recognition in England of the Woolwich principle have facilitated the recovery of unlawfully levied taxes. Yet, these developments have revealed profound differences as to which defences should be made available to public authorities. The "fiscal chaos" and "passing on" defences proposed by three Justices of the Supreme Court of Canada in the Air Canada case have not been well received in Australia and England. This article traces the evolution of the traditional common law approach to the problem of unlawfully levied taxes, offers a survey of the judicial developments in this area since the past decade and proposes a comparative analysis of the approaches adopted in each jurisdiction.
Traditionnellement, la common law n'offrait que peu de soutien aux contribuables souhaitant obtenir le remboursement de taxes illégalement perçues par l'État. Puisque, règle générale, l'erreur de droit ne suffisait pas en soi pour justifier un recours en restitution et puisque les tribunaux refusaient de conclure que des sommes perçues par l'État avaient nécessairement été payées sous contrainte, les contribuables se trouvaient souvent sans recours. Heureusement, d'importants développements jurisprudentiels ont eu lieu au Canada, en Australie et en Angleterre au cours de la dernière décennie. $L$ 'abandon de la règle de l'erreur de droit, dans les trois juridictions, el l'arrèt de la Chambre des Lords dans l'affaire Woolwich ont contribué à faciliter le remboursement de laxes illégalement perçues. Cependant, ces développements ont révélé d'importantes divergences quant aux défenses pouvant être invoquées par l'État. La règle du "chaos fiscal" et la défense du report de l'enrichissement sur autrui, proposées par trois juges de la Cour suprème du Canada dans l'arrêt Air Canada, n'ont pas été favorablement reçues en Australie et en Angleterre. L'article trace l'évolution des règles de common law traditionnelles relatives au remboursement de taxes illégalement perçues, offre un compte rendu des développements jurisprudentiels ayant eu lieu en la matière durant la dernière décennie et propose une analyse comparative de l'approche retenue dans chaque pays.

\section{TABLE OF CONTENTS}

I. INTRODUCTION $\ldots \ldots \ldots \ldots \ldots \ldots \ldots \ldots \ldots \ldots \ldots \ldots \ldots$

II. THE PROBLEM IN CONTEXT $\ldots \ldots \ldots \ldots \ldots \ldots \ldots \ldots \ldots 9 . \ldots 96$

A. THE BROADER CONTEXT: THE RECOGNITION

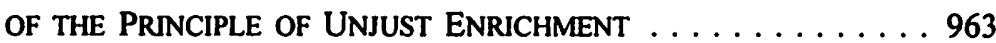

B. THE TRAditional OBSTACles:

Mistake of LAW aNd COMPULSION . . . . . . . . . . . . . . 967

III. THE DEVELOPMENTS IN CANADA, Australia, AND ENGLAND . . . 973

A. THE ABANDONMENT OF THE BILBIE RULE IN

CANADA: AIR CANADA AND CANADIAN PACIFIC . . . . . . 973

LL.B. (Montréal); LL.M. (Cantab.) chargé de cours, Faculté de droit, Université de Montréal. The author is grateful to his dear friend, Stéphane Beaulac, for his helpful suggestions and comments on a draft of the author's LL.M. thesis, on which the present article is partly based. 


\section{B. THE REJECTION OF THE BILBIE RULE BY THE HIGH COURT OF AUSTRALIA: DAVID SECURITIES}

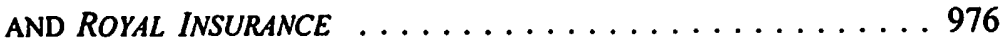

C. THE AdOPTION OF THE WOOLWICH PRINCIPLE IN ENGLAND . . 978

IV. COMPARATIVE ANALYSIS OF THE DEVELOPMENTS IN

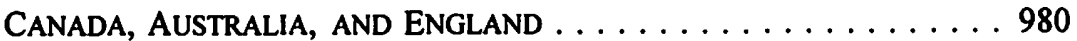

A. FACILITATING THE RECOVERY OF UNLAWFULLY

LEVIED TAXES: THE APPROACHES COMPARED . . . . . . 980

B. The "Fiscal ChaOs" and "Passing ON" Defences:

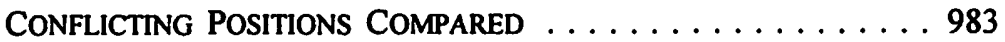

V. CONCLUSION .......................987

\section{INTRODUCTION}

Ask any layperson whether taxpayers should, as a general rule, be able to recover taxes that have been unlawfully levied' by public authorities and, most likely, his or her answer will instinctively be in the affirmative. Basic fairness and common justice seem to allow for no other conclusion. However, the common law traditionally has not been sympathetic to unlawfully deprived taxpayers. Establishing that public authorities had no legal entitlement to levied sums was not in itself sufficient for a restitutionary claim to succeed. Taxpayers had to establish that the impugned payment had been made under either a mistake or compulsion. In many situations, they were left without a remedy, primarily because of two important obstacles which barred recovery.

The first obstacle was that payments made under a mistake of law - that is, under the mistaken belief that they were legally owed to public authorities - were as a general rule not recoverable at common law. Only payments made under a mistake of fact were recoverable. Secondly, unlike the situation prevailing for example under Quebec law, ${ }^{2}$ courts refused to consider the mere fact that moneys had been levied by public authorities as amounting to compulsion.

In the past decade or so, important judicial developments in Canada, ${ }^{3}$ Australia, and

At the outset, it may be useful to point out that there are generally two ways in which taxes can be unlawfully levied. The first is pursuant to the authority of a statutory or regulatory provision subsequently found to be invalid or unconstitutional. The second is through the misinterpretation or misapplication of an otherwise valid statutory or regulatory provision.

See the decision of the Supreme Court of Canada in Wilmor Discount Corp. v. Vaudreuil (City), [1994] 2 S.C.R. 210 [hereinafter Wilmor] at 219, where reference was made to J. Pineau \& D. Burman, Théorie des obligations, 2d ed. (Montreal: Thémis, 1988) at 246.

3 As this article is concerned with developments that occurred at common law, references to Canada exclude the Province of Quebec, where the system of private law is one of civil law tradition. In Quebec, the recovery of unlawfully levied taxes is governed by the provisions of the Civil Code relating to the reception of a thing not due (art. 1491-1492 C.C.Q.) as well as those relating to the restitution of prestations (art. 1699-1707 C.C.Q.), the application to public authorities of which is confirmed by art. 1376. As is typically the case in civil law jurisdictions, recovering unlawfully levied taxes in Quebec has not been as problematic as it has traditionally been in common law jurisdictions: see Wilmor, ibid. at 219-20, Abel Skiver Farm Corp. v. Town of Ste-Foy, [1983] 1 S.C.R. 403. For an overview of the unjust enrichment in civil law jurisdictions, see K. Zeigert \& H. 
England have, generally speaking, facilitated the recovery of unlawfully levied taxes. These developments, which have been significantly influenced by the extensive criticism which the traditional common law rules governing the restitution of unlawfully levied taxes have attracted in the last two decades, have taken place while the law of restitution underwent profound changes, the full implications of which can only be speculated upon. The recognition of the principle of unjust enrichment as a theoretical basis common to all claims in restitution has provided the law of restitution with a unifying analytical framework that had been lacking for centuries. This is expected to favour coherence in future developments in this area of the common law. It has prompted courts to reconsider principles thought to be immune to judicial reform ${ }^{4}$ by looking at traditional restitutionary rules through the prism of unjust enrichment. It has also certainly played a role in the important judicial developments that have affected the recoverability of unlawfully levied taxes.

Yet, while as a result of these developments unlawfully deprived taxpayers in Canada, Australia, and England are undoubtedly in a much better position today, the relevant decisions of the Supreme Court of Canada, the High Court of Australia, and the House of Lords reveal important differences in the approaches and solutions adopted in each jurisdiction. In Canada and Australia, the first of the two obstacles mentioned, the socalled mistake of law rule, has been uprooted judicially. The House of Lords on the other hand has eliminated both obstacles by ruling that taxes unlawfully levied pursuant to an ultra vires demand were, generally speaking and irrespective of whether they had been paid under a mistake or compulsion, recoverable at common law in England. Furthermore, these developments have revealed profound disagreements as to whether controversial defences (the "fiscal chaos" and the "passing on" defences) ought to be available to public authorities faced with claims aimed at recovering unlawfully levied taxes.

This article offers a survey of the recent judicial developments in Canada, Australia, and England concerning the recoverability of unlawfully levied taxes (Section III) as well

Kotz, An Introduction to Comparative Law, trans. T. Weir, 2d ed. (Oxford: Clarendon Press, 1987) at $575 \mathrm{ff}$. For a more comprehensive comparative study of the problem of unlawfully levied taxes in civil law jurisdictions, see "La restitution de taxes perçues indüment par l'État" in A. Hirsch, C.-A. Junod \& A. Macheret, eds., Études suisses de droit européen, vol. 18 (Geneva: Centre d'études juridiques européennes, 1976).

- Note that in many jurisdictions, statutory schemes have been adopted to govern the recoverability of certain types of taxes. In England: U.K., Law Commission, Restitution: Mistakes of Law and Ulira Vires Public Authorities Receipts and Payments (London: H.M.S.O., 1994) [hereinafter U.K. Law Commission] at 71-74; J. Beatson, "Restitution of Taxes, Levies and Other Imposts: Defining the Extent of the Woolwich principle" (1993) 109 L.Q. Rev. 401 at 418-25. In Australia: K. Mason \& J.W. Carter, Restitution Law in Australia (Sydney: Butterworths, 1995) at 772 and 776-78. In British Columbia: Law Reform Commission of British Columbia, Report on Benefits Conferred Under a Mistake of Law (Vancouver: Law Reform Commission of British Columbia, 1981) at 95-108. In the United States: O.P. Field, "The Recovery of Illegal and Unconstitutional Taxes" (1932) 45 Harv. L. Rev. 501; E.M. Perkins, "Tax Injunctions and Suits to Recover Taxes Paid Under Protest in North Carolina" (1933) 12 N.C. L. Rev. 20.

5 The House of Lords has, since these developments occurred, abandoned the mistake of law rule in non-tax contexts: Kleinwort Benson Lld. v. Lincoln City Council, [1998] 4 All E.R. 513 (H.L.) [hereinafter Kleinwort]. 
as a comparative analysis primarily focusing on the significance of the differences in the approaches and solutions adopted in each jurisdiction (Section IV). At the outset, the problem of unlawfully levied taxes in common law jurisdictions will be placed in context by first considering in more detail the significance of the recognition of the principle of unjust enrichment and, second, analyzing the evolution of the common law rules which failed to provide fair and satisfactory remedies to unlawfully deprived taxpayers (Section II).

\section{The Problem in Context}

\section{A. The Broader Context: THE Recognition of THE PRINCIPLE OF UNJUST ENRICHMENT}

The traditional failure of English law to acknowledge the fundamental relationship the prevention of unjust enrichment - between restitutionary claims is well documented. ${ }^{6}$ It prevented the development of a coherent and consistent body of rules not only aimed at achieving a common purpose, but also at functioning logically with one another. The law of restitution consisted of "a collection of fact-specific categories in which recovery was permitted." Recoverability was not governed by a general principle providing for more detailed rules depending on specific circumstances as in civil law jurisdictions, but rather by various sets of rules applicable independently to each category, with little regard for one another. It "provide[d] specific remedies in particular cases of what might be classified as unjust enrichment in a legal system that is based upon the civil law."

6 I have found the following works and texts to be most useful to understand the evolution of the law of restitution in England: J.H. Baker, "The Use of the Assumpsit for Restitutionary Money Claims 1600-1800" in E.J.H. Schrage, ed., Unjust Enrichment - The Comparative Legal History of the Law of Restitution (Berlin: Duncker \& Humblot, 1995); J.P. Dawson, Unjust Enrichment - A Comparative Analysis (Boston: Little Brown, 1951); H.C. Gutteridge \& R.J.A. David, "The Doctrine of Unjustified Enrichment" (1935) 5 C.L.J. 204; J. Hallebeek, "Developments in Medieval Roman Law" in E.J.H. Schrage, ed., ibid.; R.M. Jackson, History of Quasi-Contract in English Law (Cambridge: Cambridge University Press, 1936); D. Ibbetson, "Implied Contracts and Restitution: History in the High Court of Australia" (1988) 8 Oxford J. Legal Stud. 312; P.H. Winfield, The Law of Quasi-Contracts (London: Sweet \& Maxwell, 1952) at 1-25; Zeigert \& Kotz, supra note 3 at 590ff. The general textbooks are also very helpful: R. Goff \& G. Jones, The Law of Restitution, 5th ed. (London: Sweet \& Maxwell, 1998) at 5-11; Mason \& Carter, supra note 4 at 4-34; G.E. Palmer, The Law of Restitution, vol. 1 (Boston: Little Brown, 1978) at 1-20; G.B. Klippert, Unjust Enrichment (Toronto: Butterworths, 1982) at 1-23; P.D. Maddaugh \& J.D. MacCamus, The Law of Restitution (Aurora: Canada Law Book, 1990) at 3-12; S.J. Stoljar, The Law of Quasi-Contracts, 2d ed. (Sydney: Law Books, 1989) at 1-17.

7 Peel (Regional Municipality) v. Canada, [1992] 3 S.C.R. 762 [hereinafter Peel] at 784. For comments, see: R. Chambers, "Restitution of Money Paid to Third Person: Peel (Regional Municipality) v. The Queen" (1993) 57 Sask. L. Rev. 325; M. McInnes, "Incontrovertible Benefits in the Supreme Court of Canada" (1994) 23 Can. Bus. L.J. 122; D. Stevens, "Restitution Compulsion - Municipality Paying for Support of a Juvenile Delinquent Pursuant to a Court Order - Order Made Under Ultra Vires Legislation - Municipality's Right to Recover: The Regional Municipality of Peel v. Her Majesty the Queen in Right of Canada" (1994) 73 Can. Bar Rev. 84.

- This is how Lord Diplock described the state of English law in Orakpo v. Manson Investments, [1978] A.C. 95 (H.L.) at 104, after having firmly reaffirmed the opinion of the House of Lords that "there [was] no general doctrine of unjust enrichment recognised in English law." 
The developments which are the subject of this article have occurred while the law of restitution as a whole was substantially transformed by the recognition of the principle of unjust enrichment as the unifying theoretical basis common to all restitutionary claims. The principle was initially recognized in the first paragraph of the American Restatement of The Law of Restitution: "a person who has been unjustly enriched at the expense of another is required to make restitution to the other." In Canada, it was adopted in a series of decisions of the Supreme Court, from the 1954 case of Deglman v. The Guaranty Trust Co. of Canada ${ }^{10}$ to the Pettkus v. Becker" decision in 1980. In Australia, the turning point was the 1987 decision of the High Court in Pavey \& Matthews Pty v. Paul ${ }^{12}$ while the House of Lords reached a similar conclusion four years later in its landmark decision in Lipkin Gorman v. Karpnale Ltd. ${ }^{13}$

The doctrine of unjust enrichment essentially recognizes that three elements are common to all situations in which equity and the common law provide for a right in restitution. Restitution will be allowed - provided that no defence operates to defeat the claim - where it is established that a) the defendant received a benefit, b) at the plaintiff's expense, and c) that such receipt was unjust. ${ }^{14}$ This has been taken for granted by the Supreme Court of Canada for years ${ }^{15}$ and has been extensively acknowledged in recent literature. ${ }^{16}$

American Law Institute, Restatement of the Law of Restitution - Quasi Contracts and Constructive Trusts (St. Paul: American Law Institute Publishers, 1937) [hereinafter Restatement of the Law of Restitution].

10 [1954] S.C.R. 725.

" [1980] 2 S.C.R. 834 [hereinafter Pettkus].

12 (1987), 162 C.L.R. 221 [hereinafter Pavey \& Mattews]. For comments, see: J. Siourthas, "Pavey and Matthews v. Paul and the Law of Restitution" (1989) 17 M.U.L. Rev. 324; D. Ibbetson, "Implied Contracts and Restitution: History in the High Court of Australia" (1988) 8 Oxford J. Legal Stud. 312; J. Beatson, "Unjust Enrichment in the High Court of Australia" (1988) 104 L.Q. Rev. 13.

[1991] 2 A.C. 548 [hereinafter Lipkin Gorman]. For comments, see: P.B.H. Birks, "The English Recognition of Unjust Enrichment" [1991] L.M.C.L.Q. 473; S. Fennell, "Misdirected Funds: Problems of Uncertainty and Inconsistency" (1994) 57 Mod. L. Rev. 38; B.F. Fitzgerald, "Tracing at Law, the Exchange Product Theory and Ignorance as an Unjust Factor in the Law of Unjust Enrichment" (1994) 13 U. of Tasmania L. Rev. 116; E. McKendrick, "Restitution, Misdirected Funds and Change of Position" (1992) 55 Mod. L. Rev. 377; P.G. Watts, "Unjust Enrichment and Misdirected Funds" (1991) 107 L.Q. Rev. 521.

The requirement that no defence operate to defeat the claim is sometimes stated as a fourth element of the principle; see, for example, Birks, ibid. at 475.

is Examples include: Rathwell v. Rathwell, [1978] 2 S.C.R. 436 at 455; Pettkus, supra note 11 at 848 ; Sorochan v. Sorochan, [1986] 2 S.C.R. 38 at 44; Peel, supra note 7 at 784; Peter v. Beblow, [1993] 1 S.C.R. 980 [hereinafter Beblow].

16 Most notably by the authors of the leading textbook on the law of restitution in the common law world, Goff \& Jones, supra note 6 at 15. 
The principle of unjust enrichment replaces the infamous "implied contract theory"17 as the theoretical basis underlying all claims in restitution. ${ }^{18}$ Deane J., writing for a majority of the High Court of Australia in Pavey\& Matthews, explained that the principle "constitutes a unifying legal concept which explains why the law recognizes, in a variety of distinct categories of cases, an obligation on the part of a defendant to make fair and just restitution for a benefit derived at the expense of a plaintiff."19 To Lord BrowneWilkinson, "the concept of unjust enrichment lies at the heart of all individual instances in which the law does give a right of recovery."20

A more difficult question concerns the implications that the recognition of the doctrine of unjust enrichment will have on the traditional restitutionary categories that have developed over the centuries. It certainly has not given judges carte blanche to decide restitutionary claims on the basis of justice or fairness alone. "To identify the basis of such actions as restitution and not genuine agreement is not to assert a judicial discretion to do whatever idiosyncratic notions of what is fair and just might dictate," the High Court of Australia has held." The Supreme Court of Canada has also made this point clear in its decision in Peel. ${ }^{22}$

Moreover, a review of the decisions of the High Court of Australia, the Supreme Court of Canada, and the House of Lords reveals that the advent of the doctrine of unjust enrichment has not completely obliterated the traditional restitutionary categories and the precedents upon which they are based. These precedents are still relevant to the determination of the success of a restitutionary claim in the circumstances of a given case. Yet, the extent to which the traditional categories remain relevant to the determination of the success of a restitutionary claim remains unclear. To some, the doctrine of unjust enrichment "must not be mistaken for a rule of immediate liability.... It merely coordinates and gives direction to the many specific grounds for restitution." ${ }^{23}$ Recent decisions of the High Court of Australia and the House of Lords suggest that the principle will not have a broader impact on traditional restitutionary categories. ${ }^{24}$

The "implied contract theory" appeared during the 17th century to provide a theoretical explanation to quasi-contractual claims. It has been extensively criticized in the past decades. There is abundant literature on the subject and some texts are collected in Goff \& Jones, supra note 6 at 6 (n. 12). Klippert, supra note 6 at c. 2; Maddaugh \& McCamus, supra note 6 at 13-21; Mason \& Carter, supra note 4 at $25 \mathrm{ff}$; Birks, supra note 13. See also Westdeutsche Landesbank Girozentrale v. Islington London Borough Council, [1996] A.C. 669 (H.L.) at 710. Supra note 12 at 257.

Woolwich Equitable Building Society v. Inland Revenue Commissioners, [1993] A.C. 70 (H.L.) [hereinafter Woolwich] at 197. For comments, see D. Wilde "A Revolutionary Approach to Unlawful Taxation" [1995] B.T.R. 137; T. Hill, "Restitution From Public Authorities and the Treasury's Position: Woolwich Equitable Society v. IRC' (1993) 56 M.L. Rev. 856; Beatson, supra note 4; P.B.H. Birks, "'When Money is Paid in Pursuance of a Void Authority...' - A Duty to Repay?" [1992] P.L. 580; E. McKendrick, "Restitution of Unlawfully Demanded Taxes" [1993] L.M.C.L.Q. 88.

Pavey \& Matthews, supra note 12 at 256. See Goff \& Jones, supra note 6 at 15. Supra note 7 at 802-805. See also Beblow, supra note 15 at 988; Stevens, supra note 7 at 93. Birks, supra note 13 at 475 . See also: A. Burrows, The Law of Restitution (London: Butterworths, 1993) at 21; McKendrick, supra note 20 at 93. 
However, recent decisions of the Supreme Court of Canada suggest that it holds a very different view and that the emergence of the principle of unjust enrichment has fundamentally altered the way in which restitutionary claims are to be regarded. In Peel, the Court addressed in detail the relationship between the traditional restitutionary categories and the doctrine of unjust enrichment. ${ }^{25}$ It noted that there are two doctrinal approaches to claims in restitution. The first, the "category approach," involves (as its name suggests) analyzing restitutionary claims by reference to the traditional common law restitutionary categories. The second, the "principled approach," involves analyzing restitutionary claims by reference to the tri-partite principle of unjust enrichment. After having analyzed the various tensions between both approaches and the policy considerations involved with each, McLachlin J., as she then was, wrote:

This case presents the court with the difficult task of mediating between, if not resolving, the conflicting views of the proper scope of the doctrine of unjust enrichment. It is my conclusion that we must choose a middle path; one which acknowledges the importance of proceeding on general principle but seeks to reconcile the principle with the established categories of recovery; one which charts a predictable course without falling into the trap of excessive formalism; one which recognizes the importance of the right to choose when to spend one's money while taking account of legitimate expectations and what, in light of those expectations, is fair. ${ }^{26}$

After having reviewed the evolution of the law of restitution, especially in Canada, McLachlin J. explained that the tri-partite principle of unjust enrichment is "at the basis of the cause of action for unjust enrichment."27 It has "grown out" of the traditional common law restitutionary categories although, as was pointed out by McLachlin J., it remains "informed" by them. In Peel, the Court made it very clear that while instructive, the traditional categories of restitution ought not to be viewed as final determinants of whether a claim would lie in the particular circumstances of a given case. ${ }^{28}$ In other words, the tri-partite principle of unjust enrichment is, in Canada, the ultimate measure of whether a right in restitution exists. A restitutionary claim can no longer be analyzed by sole reference to the traditional "categories" caselaw. The significance of this novel approach to the analysis of restitutionary claims is illustrated by the subsequent decision of the Court in Beblow, a case in which the Court expanded the elements relevant to the third branch of the principle (absence of juristic reason for the impugned enrichment) with little regard to the traditional restitutionary categories. ${ }^{29}$

The Court was unanimous on this issue.

Peel, supra note 7 at 786.

Ibid. at 788 [emphasis added].

lbid. at 789.

Supra note 15. As is illustrated by the following passage of McLachlin J.'s reasons (at 990-91): What matters should be considered in determining whether there is an absence of juristic reason for the enrichment? The test is flexible, and the factors to be considered may vary with the situation before the court. For example, different factors may be more relevant in a case like Peel, supra, at p. 803, a claim for unjust enrichment between different levels of government, than in a family case.

In every case, the fundamental concern is the legitimate expectation of the parties: Pettkus $v$. Becker, supra. In family cases, this concem may raise the following subsidiary questions:

(i) Did the plaintiff confer the benefit as a valid gift or in pursuance of a valid common law, equitable or statutory obligation which he or she owed to the defendant? 
Yet, despite the uncertainties relating to its implications on the law of restitution, the emergence of the doctrine of unjust enrichment has undeniably contributed to the establishment of a climate favourable to the judicial reconsideration of traditional rules. These may prove difficult to justify when looked at through the prism of unjust enrichment. Only time will tell how the advent of this new doctrine will transform the law of restitution; however, if the spectacular demise of the mistake of law rule is any indication, it may not be exaggerated to say, as Professor Birks has written, that Lipkin Gorman was to English law "the Donoghue v. Stevenson of restitution."

\section{B. The Traditional Obstacles: Mistake of LaW and Compulsion}

Traditionally, taxes unlawfully levied by public authorities were only recoverable in specific, rather narrow, circumstances. There was no such thing as a general right to recover taxes unlawfully levied by public authorities. ${ }^{31}$ Restitution could only succeed if a taxpayer could fit his or her case in either one of the two main categories recognized as giving rise to a restitutionary claim: mistake and compulsion. However, as I have mentioned at the outset of this article, only payments made under a mistake of fact (not those made under a mistake of law) were generally recoverable, and the mere fact that a payment had been made pursuant to a demand from public authorities was not in itself sufficient to establish compulsion. Thus, taxpayers were in many situations left without a remedy.

The situation would certainly have been different had Lord Ellenborough avoided the "monstrous mistake of law"32 he made in Bilbie v. Lumley ${ }^{33}$ when he dismissed the plaintiff's claim for restitution founded on the later-revealed fact that the impugned payments were not legally owed. He did so on the basis that every man had to be cognizant of the law, thereby laying the foundation ${ }^{34}$ of the rule that payments made

(ii) Did the plaintiff submit to, or compromise, the defendant's honest claim?

(iii) Does public policy support the enrichment?

Birks, supra note 13 at 474 . In Mason \& Carter, supra note 4 at 4 , the authors have described these changes as amounting to a "revolution in the approach to the [law of restitution]."

G. Jones, "Restitutionary Claims against Public Authorities: A Comparative Study" in G. Jones, ed., Restitution in Public and Private Law (London: Sweet \& Maxwell, 1991) 1 at 3. Note that the circumstances of a given case could indicate that a payment had been received by public authorities on the implied agreement that it would be reimbursed if it later turned out to have been levied without legal authority. It would thus be recoverable in contract: Sebel Products v. Customs and Excise Commissioners, [1949] Ch. 409.

12 W.E. Patterson, "Improvements in the Law of Restitution" (1954-55) 40 Cornell L.Q. 667 at 676, cited by Dickson J., dissenting, in Nepean Hydro Electric Commission v. Ontario Hydro, [1982] 1 S.C.R. 347 [hereinafter Nepean]. Surprisingly, nine years after Bilbie, Lord Ellenborough himself allowed restitution of moneys on the basis that they had been paid under a mistake of law, writing that it was "difficult upon principle" to defend that a mistake of law should not be treated in the same manner as a mistake of fact: Perrot v. Perrot (1811), 104 E.R. 665.

(1802), 102 E.R. 448 [hereinafter Bilbie].

The later decision of the Court of Common Pleas in Brisbane v. Dacres (1813), 128 E.R. 641, in which the Court declined an invitation to overrule Bilbie, is sometimes cited as the point where the rule became firmly established in English law (see: C.L. Pannam, "The Recovery of Unconstitutional Taxes in Australia and the United States" (1964) 42 Tex. L. Rev. 777 at 780; Law Reform Commission of British Columbia, supra note 4 at 12), although others point to Kelly v. Solari (1841), 
under a mistake of law were not recoverable. The Bilbie rule was, in effect, new law recovery of payments made pursuant to a mistake had previously been allowed without regards to the nature of the mistake at issue $\mathrm{e}^{35}$ - and was at the origin of the distinction between mistakes of law and those of fact. ${ }^{36}$

The Bilbie rule was followed in Australia, Canada, New Zealand, and in all but four American states; ${ }^{37}$ it has been almost universally criticized as unprincipled and unfair by commentators $^{38}$ and law reform commissions. ${ }^{39}$ Unprincipled, first because the interdiction to rely on ignorance of the law is only relevant in the context of rules having a regulatory function and, second, because invoking the need for certainty in transactions in support of the rule was inconsistent with a right in restitution of payments made under

152 E.R. 24, a case involving a mistake of fact in which Bilbie was distinguished (see: Maddaugh \& McCamus, supra note 6 at 254-55; U.K. Law Commission, supra note 4 at 10-11).

There are several reported cases, decided prior to Bilbie, in which restitution was granted for payment made pursuant to a mistake of law, including Hewer v. Bartholomew (1598), 78 E.R. 855; Bonnel v. Fouke (1657), 82 E.R. 1224; Turner v. Turner (1679), 21 E.R. 644; Farmer v. Arundel (1722), 196 E.R. 485; Landsdowne v. Landsdowne (1730), 237 E.R. 605; Bize v. Dickason (1786), 99 E.R. 1097.

The effect of the Bilbie rule in the context of claims in restitution for unlawfully levied taxes is illustrated by numerous cases. Leading English cases are: Slater v. Burnley Corp. (1888), 59 L.T. 636; William Whiteley Lid. v. R. (1909), 101 L.T. 741; National Pari-Mutuel Association Lid. v. $R$. (1930), 47 T.L.R. 110; see also U.K. Law Commission, supra note 4 at 52-53. American cases are collected in: Palmer, supra note 6 at 338 (n. 8); Palmer, ibid. (vol. III) at 248 (n. 6); Palmer, ibid. (1986 Supplement) at 253; "Annotations" (1927) 48 A.L.R. 1381 and (1931) 74 A.L.R. 1301; Restatement of the Law of Restitution, supra note 9 at 299-302. Examples of Canadian precedents are collected and discussed in: Law Reform Commission of British Columbia, supra note 4 at 14-25; see also Air Canada v. British Columbia, [1989] 1 S.C.R. 1161 [hereinafter Air Canada] at 1195-96. Some Australian precedents are discussed in Pannam, supra note 34, as well as in the decision of the High Court in David Securities Pty. v. Commonwealth Bank of Australia (1992), 175 C.L.R. 353 [hereinafter David Securities].

Pannam, ibid. at 781-82. The four American states in question are Kentucky, Connecticut, Minnesota and Missouri: ibid. See also Palmer, supra note 6 (vol. II) at 344 (n. 29); Palmer, ibid. (1986 Supplement) at 264.

The fact that the rule has been severely criticized - which is illustrated by literature so abundant that to make an exhaustive survey here would be impossible - was recently acknowledged by Lord Keith and Lord Goff, in Woolwich, supra note 20 at 174. See also: Lord Goff's speech in Kleinwort, supra note 5; David Securities, supra note 36 at 374ff; J. D. McCamus, "Restitutionary Recovery of Moneys Paid to a Public Authority Under a Mistake of Law: Ignorantia Juris in the Supreme Court of Canada" (1983) 17 U.B.C. L. Rev. 233 at 236, who went so far as to suggest that no other private law doctrine had been more criticized.

Law Reform Commission of British Columbia, supra note 4 at 58-66; Law Reform Committee of South Australia, Report Relating to the Recoverability of Benefits Obtained by Reason of Mistake of Law (Adelaide: Law Reform Committee of South Australia, 1984); New South Wales Law Reform Commission, Restitution of Benefits Conferred Under Mistake of Law (Sydney: New South Wales Law Reform Commission, 1987); Scottish Law Commission, Recovery of Benefits Conferred Under Error of Law (Discussion Paper No. 95, 1993); U.K. Law Commission, supra note 4 at 52-53 at 2933. Some legislatures even took the initiative of correcting Lord Ellenborough's mistake themselves: in New Zealand, Western Australia, New York and India (U.K. Law Commission, supra note 4 at 29; Law Reform Commission of British Columbia, supra note 4 at 68-81; Pannam, supra note 34 at 794-95; Palmer, supra note 6 (vol. III) at 374ff.). 
mistakes of fact, the argument being equally valid in such cases. ${ }^{40}$ But, beyond the theoretical analysis of whether such a rule was based on sound legal principle, there was a basic unfaimess in allowing, as a general rule, that a payee could benefit from the payer's honest mistake of law by keeping money to which he or she was not legally entitled.

Even judges found it difficult to resist criticizing the distinction. Their criticism was most often indirect and subtle because the rule had acquired, simply from the passage of time, a level of notoriety that seemed to have left it immune to judicial reform. This was exemplified by Croom-Johnson J.'s statement in 1943 "that a voluntary payment made under a mistake of law cannot be recovered is, I should have thought, beyond argument at this period in our legal history." Jul Judges instead sought to limit the effect of the Bilbie rule by creating many exceptions, ${ }^{42}$ by manipulating the distinction between mistakes of law and those of fact, ${ }^{43}$ and by adopting a more liberal approach toward the concept of compulsion. ${ }^{44}$ Nonetheless, of all the exceptions created over the years, and of all the techniques employed by judges in order to lessen the harsh impact of Lord Ellenborough's influential error, none provided a satisfactory answer to the problem of unlawfully levied taxes. ${ }^{45}$

Inevitable and predictable practical difficulties ensued, leading to criticism at another level. The numerous exceptions that had been recognized by judges over the years, and the efforts on the part of some judges to limit the rule's scope led to the creation of a confusing body of case law. The precise limits of the boundaries of the Bilbie rule became increasingly difficult to trace and its application in a practical context became often, at best, unpredictable and difficult. ${ }^{46}$ The unclear distinction between mistakes of law and 264. (1932).

For a masterful criticism of the Bilbie rule, see Dickson J.'s dissenting judgment in Nepean, supra Sawyer \& Vincent v. Window Brace, [1943] I K.B. 32 at 34.

The Law Commission of England identified no less than 10 qualifications and exceptions in its final report (see U.K. Law Commission supra note 4 at 11-15).

See Dickson J.'s dissenting judgement in Nepean, supra note 32 at 365. In George (Porky) Jacobs Lid. v. Regina (City of), [1964] S.C.R. 326, the Supreme Court of Canada characterized a mistake as to the existence of a by-law as one of fact; see, further, Maddaugh \& McCamus, supra note 6 at

Some judges were more explicit in their criticism. See Ex Parte Simmonds (1885), L.R. 16 Q.B.D. 308 at 312 and Cardozo J.'s comments in Moore Ice Cream v. Rose, 289 U.S. 373 at 378-379

Professor Birks has argued (P.B. Birks, "Restitution From Public Authorities" [1980] C.L.P. 191 [hereinafter "Restitution From Public Authorities"]; P.H. Birks, "Restitution from the Executive: A Tercentenary Footnote to the Bill of Rights" in P.D. Finn, ed., Essays on Restitution (Sydney: The Law Book Co., 1990) 164 [hereinafter "Restitution from the Executive"]) that the common law did recognize an exception to the Bilbie rule permitting restitution of payments unlawfully levied by public authorities. However, none of the cases upon which his thesis was primarily based (Steele $v$. Williams (1853), 155 E.R. 1502; Hooper v. Exeter Corporation (1887), 56 L.J.Q.B. 457; AttorneyGeneral v. Wilts United Dairies, (1921), 37 T.L.R. 884) clearly supported it and the argument was ultimately dismissed by the House of Lords in Woolwich, supra note 20.

J. Beatson, The Use and Abuse of Unjust Enrichment (Oxford: Clarendon Press, 1991) at 163; McCamus, supra note 38 at 235-36; R.D. Collins, "Restitution from Government Officials" (1984) 29 McGill L.J. 407 at 409; Law Reform Commission of British Columbia, supra note 4 at 64-66. 
those of fact has been described as "a fluttering, shadowy will-o'-the-wisp." 47 Goff and Jones in the opening sentence of chapter four wisely warn the readers of their treatise, that "[f]ew subjects are more confused than recovery of money paid under a mistake of law." 48

In the specific context of taxes unlawfully levied by public authorities, the evolution of the Bilbie rule and the concept of compulsion seem somewhat paradoxical. On the one hand, the unfaimess of these rules in that specific context, as well as the judiciary's dissatisfaction with it led to the emergence of exceptions specifically designed to allow recovery against public authorities - like that permitting recovery against officers of the court, first recognized in Ex parte James. ${ }^{49}$ In the same vein, courts in all common law jurisdictions sought to extend the concept of compulsion so as to facilitate restitution against public authorities. A significant and important body of case law emerged in support of a right in restitution of "money paid to a person in a public or quasi-public position to obtain the performance by him of a duty which he is bound to perform for nothing or for less than the sum demanded by him ... to the extent that he is not entitled to it." ${ }^{\text {so }}$ The threatened withholding of a legal entitlement unless the payment is made - inherent in such situations - was held to amount to compulsion and to render involuntary any payment made in order to obtain the entitlement in question. A payment unlawfully levied as a condition of renewing a license ${ }^{51}$ or an unlawfully levied toll $1^{52}$ was recoverable on that basis. A right in restitution to such payments, known as payments made ex colore officii ("by colour of office"), was also recognized in Australia ${ }^{53}$ and, to

Per La Forest J. in Air Canada, supra note 36 at 1199.

Goff \& Jones, supra note 6.

(1874), L.R. 9 Ch. App. 609. Another interesting example is the non in pari delicto exception established in Kiriri Cotton Co. v. Dewani, [1960] A.C. 192 (P.C.), which allows restitution of money paid under an illegal transaction where the illegality was designed to protect a given section of the community of which the plaintiff was part. See also Eadie v. The Corporation of the Township of Brantford, [1967] S.C.R. 573, where the Supreme Court suggested, at 583, that this exception could extend so as to support a right in restitution for unlawfully levied taxes paid as a result of a mistake of law. A majority of the Court ultimately rejected such a proposition in Nepean, supra note 32 at 393-94. See also Air Canada, supra note 36 at 1208-209. The Eadie obiter remark seems to have been revived by the Supreme Court of Canada in its recent decision in Air Canada v. Ontario (Liquor Control Board), [1997] 2 S.C.R. 581 at 612-13. It was cited by the Court as support for the proposition that restitution of taxes levied pursuant to the misapplication of a statute did not depend on a finding of bad faith on the part of public authorities. The above-mentioned passages of Nepean and Air Canada were not referred to by the Court. The Supreme Court's resort to the Eadie obiter comment is strange because it could have justified its reasoning by the Court's abandonment of the mistake of law rule, which will be discussed infra in section III.B.

Per Lord Goff, in Woolwich, supra note 20 at 164 . Lord Goff's words reflect Windeyer J.'s classic statement of the principle in the Australian case Mason v. New South Wales (1959), 102 C.L.R. 108 [hereinafter Mason] at 140. A meticulous analysis of the cases upon which the ex colore officii principle is based can be found in Lord Keith and Lord Jauncey's speeches in Woolwich, supra note 20.

Morgan v. Palmer (1824), 2 B. \& C. 729; Brocklebank Lid. v. The King, [1924] I K.B. 647, [1925] I K.B. 52.

Parsons v. Blandy (1810), Wight. 22.

See Mason, supra note 50 at 140; Mason \& Carter, supra note 4 at 173ff. See also Stoljar, supra note 6 at 64-78. 
a degree that remained uncertain, in Canada. ${ }^{54}$ Also noteworthy are developments that occurred in the United States, where the judiciary has always been more permissive with respect to compulsion..$^{35}$ For example, the mere possibility that a penalty could be imposed for non-payment of a tax could amount to compulsion, depending on the nature and extent of the penalty. ${ }^{36}$

On the other hand, concerns about the consequences to public finances that restitutionary claims against public authorities could potentially have led some judges and commentators to adopt a more restrictive approach toward restitution against public authorities. Where the Bilbie rule prevented recovery of moneys unlawfully levied by public authorities as the result of a mistake of law, such concerns were sometimes relied upon to justify maintaining the rule. ${ }^{57}$ Significantly, in the United States these concerns led to the adoption, in jurisdictions where the Bilbie rule had been abandoned either judicially or by way of legislative amendment, ${ }^{58}$ of a rule of non-recovery where taxes had been levied under a statute subsequently declared unconstitutional. ${ }^{59}$

These seemingly paradoxical developments bring to light the specificity of restitutionary claims against public authorities and the need to approach the problem in a distinctive manner, due to the different policy issues they raise. In a sense, given the great amount of literature the subject has recently generated, and given the extent to which commentators have gone in order to point to the specific problems raised by such claims, it is rather surprising that, until twenty years ago, restitutionary claims against public authorities received so little attention outside the United States. ${ }^{60}$ True, exceptions to the Bilbie rule and more liberal approaches to the concept of compulsion were adopted by the judiciary, thereby indicating a need for reform in that specific area of the law, but the distinctiveness of restitutionary claims against public authorities was never adequately

See Collins, supra note 46.

This distinctiveness is illustrated by developments relating to the concept of economic duress which occurred much sooner than in any other jurisdiction: Goff \& Jones, supra note 6 at 327ff; Mason \& Carter, supra note 4 at $175 \mathrm{ff}$.

Palmer, supra note 6 (vol. II) at $338 \mathrm{ff}$.

Such a rationale for the Bilbie rule was cited in American, Australian, Canadian, and Scottish cases:

Field, supra note 4 at 516; Pannam, supra note 34 at $790-91$.

Palmer, supra note 6 (vol. III) at $248 \mathrm{ff}$.

This line of cases has been approved by the leading American commentator on the law of restitution: ibid. See also "Restitution From Public Authorities," supra note 45 at 205.

Professor Birks explained this phenomenon by the fact that the law of restitution has, as a whole, been neglected until recently: "Restitution from the Executive," supra note 45 at 166. 
analyzed. ${ }^{61}$ This may explain why the law developed in a way that, at times, did not give due regard to the policy concerns underlying such claims.

Over the past twenty years, an impressive (both in qualitative and quantitative terms) body of literature ${ }^{62}$ has emerged, emphasizing the inadequate state of the law in the field of restitution against public authorities and analyzing, in a distinctive manner, the problems raised by the application of the traditional rules. The commentators' major contribution was, in my view, to identify the reasons for which, and the manner in which, restitutionary claims against public authorities differ from those between private entities, and the correlative need to recognize, as a general rule, the recoverability of unlawfully levied taxes. Two of the arguments ${ }^{63}$ that were put forward highlighted in a particularly compelling manner the basic unfairness and unsatisfactory state of the traditional common law rules. First, and this was in my view best articulated by Collins, ${ }^{64}$ there is an inherent element of compulsion in every demand for payment made by public authorities. This results from their position of superiority vis-à-vis taxpayers as well as from the sanctions the latter face in the case of non-payment. The second argument was articulated and developed by Professors Birks and Cornish. ${ }^{65}$ Article 4 of the Bill of Rights of $1688^{66}$ established the fundamental constitutional principle that the Crown was not to levy money without the consent of Parliament. It was argued that the effect of the

The issue did cross Dixon C.J.'s mind, though, in Mason, supra note 50 at $112 \mathrm{ff}$. The case involved the recovery of levies that had been held, in previous litigation, to have been levied in violation of s. 92 of the Australian Constitution and was ultimately decided in favour of the plaintiffs on the ground that they had established duress of goods as the cause of their payments. He held, at 116-17:

For myself I entertain some doubt whether the law to be applied in the present case is the law relating to the recovery by one subject from another of moneys paid by the former in consequence of a demand by the latter lacking lawful justification... I have not been able completely to reconcile myself to the view that if the weight of a de facto governmental authority manifested in a money demand is not resisted although it is incompatible with s. 92 the money belongs to the Crown unless the payment was the outcome of the actual threatened or apprehended withholding of something to which the payer was entitled or the actual threatened or apprehended impeding of him in the exercise of some right or liberty.

B. McKenna, "Mistake of Law Between Statutory Bodies and Private Citizens" (1979) 37 U.T. Fac.

L. Rev. 223; "Restitution From Public Authorities," supra note 45; McCamus, supra note 38; Collins, supra note 46; W.R. Cornish, "'Colour of Office': Restitutionary Redress Against Public Authorities" [1987] J.M.C.L. 41; "Restitution from the Executive," supra note 45); A. Burrows, "Public Authorities, Ultra Vires and Restitution" in Andrew Burrows, ed., Essays in the Law of Restitution (Oxford: Clarendon Press, 1991); Law Commission (England), Restitution of Payments Made Under a Mistake of Law, Law Com. Consultation Paper No. 120, 1991; Jones, supra note 31; U.K. Law Commission, supra note 4.

Other arguments were advanced to establish the need to treat such demand in a distinctive manner. Most convincing was that based on the unfaimess resulting from the fact that the common law had firmly recognized for years the unlimited and unconditional right of public authorities to recover any moneys they had unlawfully paid out of the public treasury: Auckland Harbour Board v. R., [1924] A.C. 318 (P.C.).

Collins, supra note 46 at $429 \mathrm{ff}$.

is "Restitution From Public Authorities," supra note 45; "Restitution from the Executive," supra note 45; Cornish, supra note 62 . Their contribution was acknowledged by Lord Goff in his speech in Woolwich, supra note 20 at 166. 
traditional restitutionary rules - which barred recovery of unlawfully levied taxes in many situations - was contrary to that provision of the Bill of Rights.

In sum, the traditional common law obstacles to a general principle of recoverability of unlawfully levied taxes have over the years been attacked from all sides. The infamous mistake of law rule was widely discredited, as was the courts' refusal to recognize the element of compulsion inherent in every demand for payment made by public authorities. These criticisms have contributed to the establishment of a climate favourable to judicial reconsideration of the traditional common law rules governing the restitution of unlawfully levied taxes. However, one cannot help but notice how little the commentators' criticisms of the traditional rules have taken into account the broader changes to the law of restitution that have resulted from the recognition of the principle of unjust enrichment. Indeed, few authors have sought to analyze the problem with regard to the tri-partite framework discussed earlier or, as I prefer to put it, by looking at the problem through the prism of unjust enrichment. This is, to a certain extent, surprising because the principle of unjust enrichment could have been relied upon to justify a departure from the traditional common law rules - and consequently invoked as additional justification for the recognition of a general rule allowing for the restitution of unlawfully levied taxes by highlighting that, at least prima facie, there is no valid juristic reason why an unlawfully deprived taxpayer should not, as a general rule, be allowed to seek restitution of the impugned sum.

\section{The Developments in Canada, Australia, ANd England}

Recent judicial developments concerning the recoverability of unlawfully levied taxes, while all ultimately aimed at facilitating the restitution of unlawfully levied taxes, have followed different directions in the three jurisdictions on which I have chosen to focus. In Canada and Australia, courts were primarily - but not solely - concerned with the mistake of law rule. In England, the House of Lords created a new restitutionary category independent from mistake and compulsion, and established a general rule favouring the recoverability of taxes levied pursuant to an ultra vires demand. Furthermore, the courts have not adopted consistent approaches as to whether public authorities should be able to defeat restitutionary claims in such contexts by relying on the controversial "fiscal chaos" and "passing on" defences.

\section{A. The abandonment of the Bilbie Rule in Canada: AIR CANADA ${ }^{67}$ AND CANADIAN PACIFIC ${ }^{68}$}

Between 1974 and 1976, the government of British Columbia levied gasoline taxes that were later found to be unconstitutional. This constituted indirect taxation which, under the Constitution Act, $1867^{69}$ can only be validly enacted by the federal Parliament. The Legislature sought to remedy the situation by adopting a direct tax which applied retroactively so as to cover the period during which taxes were unlawfully levied under

68 Canadian Pacific Airlines v. British Columbia, [1989] I S.C.R. 1133 [hereinafter Canadian Pacific].

69 (U.K.), 30 \& 31 Vict., c. 3, reprinted in R.S.C. 1985, App. II, No. 5. 
the initial ultra vires scheme. The plaintiffs challenged the constitutionality of the remedial scheme. British Columbia, they claimed, was merely trying to do directly what it could not do indirectly. The ratio decidendi of the Court's ruling, insofar as it related to the recoverability of the unlawfully levied taxes, is fairly narrow. A majority of the Court found that provincial legislatures could indeed enact legislation which operated retrospectively so as to render valid payments initially unlawfully levied, as long as the relevant enactment was otherwise constitutionally valid. Wilson J. dissented. She was of the view that such a conclusion flew in the face of the decision in Amax Potash ${ }^{70}$ in which the Supreme Court of Canada had held that a statute prohibiting the recovery of taxes held to have been enacted unconstitutionally was itself unconstitutional.

La Forest J., who penned the leading judgment with which Lamer J. (as he then was) and L'Heureux-Dubé J. concurred, addressed several issues that would have arisen had the majority found the retroactive provisions to be unconstitutional. He considered, in obiter dictum, whether the plaintiffs would have had a right to recover the impugned taxes at common law. His reasoning led him to consider whether the Bilbie rule should have constituted an obstacle to the plaintiffs' claim. "Only seven years after a majority of the Supreme Court had seemingly reaffirmed the applicability of the Bilbie rule in Canada despite a powerful and convincing dissent by Dickson J. (as he then was), ${ }^{72}$ La Forest J. decided that the time had come to abandon the Bilbie rule in Canada. ${ }^{73} \mathrm{He}$ found support in the extensive criticism the rule had endured over the years and adopted as his own Dickson J.'s remarks in Nepean. It is important to note that the latter had alluded to the emergence of the principle of unjust enrichment as a key factor justifying the abandonment of the mistake of law rule. ${ }^{74}$ Once the principle of unjust enrichment had been recognized as the theoretical basis underlying all claims in restitution, any distinction between mistakes of law and those of fact became untenable.

That La Forest J.'s views on the Bilbie rule were strictly obiter in Air Canada has led some commentators to express doubts about as to whether it was still applicable in

Amax Potash v. Government of Saskatchewan, [1977] 2 S.C.R. 576.

Wilson J. took a different approach in her dissenting reasons - not unlike that adopted by the House of Lords a few years later in Woolwich, supra note 20. She held that reconsidering the Bilbie rule would not have been necessary to rule on the plaintiff's claim, had the Court found that the remedial scheme at issue was unconstitutional. In her opinion, the common law ought to recognize the recoverability of taxes levied pursuant to an invalid enactment, irrespective of whether the impugned payments had been made under a mistake or compulsion: see Air Canada, supra note 36 at 1214-15. The decision of the majority in Nepean, supra note 32, has been interpreted as reaffirming the correctness of the Bilbie rule in Canada: McCamus, supra note 38; Collins, supra note 46; G.H.L. Fridman, "No Justice for Taxpayers: The Paucity of Restitution" (1990) 19 Man. L.J. 303 at 305. However, it is important to point out that Estey J., who wrote the majority opinion, made it very clear that the appellant had not asked the Court to abandon the Bilbie rule and that his reasons were thus confined to the operation of the rule as it had been argued: Nepean, ibid. at 412-13. This was emphasized by La Forest J. in Air Canada, supra note 36 at 1200-201.

Professor Fridman (ibid.) wrote a most vitriolic article on La Forest J.'s reasons in Air Canada. He went as far as to characterize the views expressed by La Forest J. as "extraordinary and perverse," and the manner in which he dismissed the weight of the majority's ruling in Nepean as "cavalier" (ibid. at 305-306). Such criticism seems to me unfair and unfounded since, as I pointed out in note 72, Nepean should not be read as an endorsement of the Bilbie rule. 
Canada. ${ }^{75}$ However, their concerns overlook the fact that on the same day reasons in Air Canada were released, the Court rendered its decision in Canadian Pacific. ${ }^{76}$ In that case the Court's abandonment of the Bilbie rule formed part of the ratio decidendi of its decision. In my opinion, the Bilbie rule has definitively been put to rest by the Supreme Court of Canada in Canadian Pacific.

La Forest J.'s important obiter remarks in Air Canada was not limited to a reconsideration of the Bilbie rule. He made key observations on two very important issues pertaining to the limits that ought to be imposed on the ability of taxpayers to recover unlawfully levied taxes at common law. First, La Forest J. was of the view that restitution could not as a general rule be allowed, where the unlawfulness of the impugned levies stemmed from unconstitutional legislation rather than from misapplied or misinterpreted (but otherwise constitutionally valid) legislation. ${ }^{77}$ To La Forest J., such a limitation was justified for two reasons. The first of these is fear of the fiscal chaos that could ensue should restitution be permitted, the probability of which he thought to be greater in cases where the unlawfulness has constitutional origins. The second reason pertained to the fact that, realistically speaking, governments otherwise "would be driven to the inefficient course of reimposing [them] either on the same, or on a new generation of taxpayers."78 La Forest J.'s views on this so-called "fiscal chaos" rule did not receive majority support. ${ }^{79}$ Wilson J. expressed her strong disagreement in her dissenting reasons, dismissing the proposed limitation on the recoverability of unconstitutionally levied taxes as fundamentally unfair. ${ }^{80}$

Second, La Forest J. believed that another limit to the plaintiffs' right to recover the impugned levies would have barred their claim had the Court not upheld the constitutional validity of the provisions at issue. He was of the view that, although the plaintiff airlines had initially borne the burden of the impugned taxes, the evidence supported the province's argument that the plaintiffs had recouped the cost of the impugned taxes by "passing it on" to their customers. The province's enrichment had, for that reason, not occurred at the expense of the plaintiffs, who had failed to discharge their burden of establishing that they had borne the burden of the tax. ${ }^{81}$ Wilson J. disagreed. She was

Professor Fridman (supra note 72 at 304) wrote that the case should in no way be authoritative on the issues relating to the law of restitution. See also: Maddaugh \& McCamus, supra note 6 at 278; S. Arrowsmith, "Restitution and Mistake of Law in Canada" (1990) 106 L.Q. Rev. 28 at 29.

76. Supra note 68.

$n \quad$ Some commentators have raised the question of whether this "fiscal chaos" rule also extended to taxes unlawfully levied as a result of the administrative invalidity of the regulatory instrument upon which they were founded: P.W. Hogg, Constitutional Law of Canada, 3d ed. (Toronto: Carswell, 1992) at 1252; Arrowsmith, supra note 75 at 31. There are indications in La Forest J.'s reasons that the rule would indeed cover such situations: Air Canada, supra note 36 at 1203, 1204 and 1206. Air Canada, ibid. at 1207.

In Peel, supra note 7, the "fiscal chaos" rule had been raised in argument, but the Court dealt with the case in such a manner that the issue did not arise. McLachlin J. wrote, at 805, that whether the Court wished to give majority support to the "fiscal chaos" rule should be left for another day. The fiscal chaos defence was considered as law by the Quebec Superior Court in Télébec Ltée v. Régie des télécommunications du Québec, [1996] R.L. 607. Air Canada, supra note 36 at 1215.

Ibid. at 1203. 
of the view that it was not necessary for the plaintiffs to demonstrate that the province's enrichment had occurred "at their expense"; what mattered in her opinion was that there was no legitimate basis upon which payments made pursuant to an unconstitutional legislation ought to be retained. ${ }^{82}$ However, in Canadian Pacific, the Court agreed that a plaintiff could not recover unlawfully levied taxes if it had acted as a mere collecting agent on behalf of public authorities and had never effectively borne the burden of the impugned levies. ${ }^{83}$

\section{B. The Rejection Of THE BILbIE RULe by the High COURT OF AUSTRALIA: DAVID SECURITIES AND ROYAL INSURANCE}

The High Court of Australia was asked to decide whether the Bilbie rule formed part of the law of Australia in David Securities, ${ }^{84}$ a case which did not involve the restitution of unlawfully levied taxes. It involved sums which had been paid under a contractual clause subsequently found to be unenforceable. The full Court had dismissed the appellants' argument on the basis that moneys paid under a mistake of law were not recoverable at common law. The majority first exposed the origins of the Bilbie rule and concluded that it had never been accepted by the High Court as forming part of the law of Australia. Some of its decisions, relied upon by the respondent to support the contrary, ${ }^{85}$ were distinguished on the basis that they pertained to the recovery of moneys paid as a result of a voluntary submission. ${ }^{86}$ The majority also alluded to the criticism that the Bilbie rule had endured and pointed out that it had gained added impetus in

It is unclear from Beetz and Mclntyre JJ.'s short reasons whether they adhered to La Forest J.'s views on this issue. P. Michell ("Restitution, 'Passing On', and the Recovery of Unlawfully Demanded Taxes: Why Air Canada Doesn't Fly" (1995) 53 U.T. Fac. L. Rev. 130 at 138) seems to suggest that they have not expressed any opinion on the matter. See, further: Arrowsmith, supra note 75; Fridman, supra note 72; R. van de Mosselear. "Recovery of Money Paid Under a Mistake of Law: Air Canada v. British Columbia" (1991) 55 Sask. L. Rev. 331. These authors are of the view that Beetz and McIntyre JJ. have expressed no opinion on the recoverability of the impugned taxes at common law.

This was the case in Canadian Pacific with respect to some of the taxes at issue in that appeal. They were to be distinguished on that basis from the those at issue in Air Canada, supra note 36: see Wilson J.'s reasons in Canadian Pacific, supra note 68 at 1158.

Supra note 36. For comments, see: B.C. Wells, "Restitution from the Crown: Private Rights and Public Interests" (1994) 16 Adelaide L. Rev. 191; M. Bryan, "Mistaken Payments and the Law of Unjust Enrichment: David Securities Pty Ltd. v. Commonwealth Bank of Australia" (1993) 15 Sydney L. Rev. 461; P.G. Watts, "Mistaken Payments and the Law of Restitution" (1993) L.M.C.L.Q. 145; K.-W. Liew, "Recovery of Moneys Paid Under a Mistake of Law: The Australian Approach" (1994) 6 Corp. \& Bus. L.J. 157; P.B. Birks, "Modernising the Law of Restitution" (1993) 109 L.Q. Rev. 164.

Werrin v. The Commonwealth (1938), 59 C.L.R. 150 and South Australia Cold Stores v. Electricity Trust of South Australia, (1957) 98 C.L.R. 65.

A payment is made under a voluntary submission when "the plaintiff chooses to make the payment even though he or she believes a particular law or contractual provision requiring the payment is, or may be, invalid, or is not concerned to query whether payment is legally required; he or she is prepared to assume the validity of the obligation, or is prepared to make the payment irrespective of the validity or invalidity of the obligation, rather than contest the claim for payment": David Securities, supra note 36 at 373-74. The uncertain scope of this principle is discussed in Bryan, supra note 84 at $475 \mathrm{ff}$. 
Australia since the recognition of the principle of unjust enrichment. ${ }^{87}$ It concluded that there was no reason why the Bilbie rule should form part of the law of Australia: "the payer will be entitled prima facie to recover moneys paid under a mistake if it appears that the moneys were paid by the payer in the mistaken belief that he or she was under a legal obligation to pay the moneys or that the payee was legally entitled to payment of the moneys."

Shortly thereafter, in Commissioner of State Revenue v. Royal Insurance Australia, ${ }^{89}$ the High Court was presented with a case involving the restitution of unlawfully levied duties which had been paid under a mistake of law. The dispute involved the interpretation of a statutory provision empowering public authorities to refund overpaid stamp duties. The resolution of the questions of statutory interpretation raised required that the High Court determine whether the respondent had a right to restitution at common law. The High Court applied David Securities and found that the respondent did have a prima facie right in restitution at common law. ${ }^{90}$

Royal Insurance is important for two other reasons. First, the Court rejected the "passing on" defence discussed by La Forest J. in Air Canada. Brennan J. (as he then was), with whom Toohey and McHugh JJ. concurred, reiterated what had been held in Mason," namely that such a defence was not "available to defeat a claim for moneys paid by $A$ acting on his own behalf to $B$ where $B$ has been unjustly enriched by the payment and the moneys paid had been A's moneys." ${ }^{92}$ Mason C.J. also condemned the "passing on" defence. His reasons on this issue were much more elaborate. ${ }^{93}$ The Chief Justice first explained that, as experience had demonstrated in the United States, there were numerous practical and theoretical difficulties associated with trying to determine whether - and if so to what extent - the fiscal burden initially borne by the taxpayer had subsequently been assumed by a third party. Second, his Lordship pointed out that historically, "the basis of restitutionary relief in English law was not compensation for loss of damage but restoration of what had been taken or received." 94 Inspired by Professor Birks' views, ${ }^{95}$ he wrote: "[b]ecause the object of restitutionary relief is to divest the defendant of what the defendant is not entitled to retain, the court does not assess the

87 Supra note 36 at 375 . See also Brennan J.'s reasons, at 388-93.

$88 \quad$ lbid. at 378.

89 (1994), 182 C.L.R. 51 [hereinafter Royal Insurance]. For comments, see: J. Beatson, "Restitution of Overpaid Tax, Discretion and Passing On" (1995) 111 L.Q. Rev. 375; M. McInnes, "The plaintiffs expense in restitution: difficulties in the High Court" (1995) 23 A.B.L.R. 472; P. Butler, "Restitution of Overpaid Taxes, Windfall Gains, and Unjust Enrichment: Commissioner of State Revenue v. Royal Insurance Australia Lid." (1995) 18 U. of Queensland L.J. 318.

90 In his reasons, Mason C.J. alluded to the possibility that the law recognize a general right to recover unlawfully levied taxes independent from a finding that the impugned payments were made under either a mistake or compulsion; however, he refrained to commenting further on the issue: Royal Insurance, ibid. at 68.

9 Supra note 50 at 136 and 146.

92 Royal Insurance, supra note 89 at $90-91$.

93 Ibid. at 69f.

94. Ibid. at 73.

95 P.H. Birks, An Introduction to the Law of Restitution (Oxford: Clarendon Press, 1985) at 23-24. 
amount of its award by reference to the actual loss which the plaintiff has sustained." 96 Mason C.J. accepted that "passing on" would be a valid defence where the plaintiff acted as a mere collecting agent on behalf of public authorities, as was held by the Supreme Court of Canada in Canadian Pacific. ${ }^{97}$ Clearly, in such a situation, the defendant's enrichment could not be said to have been at that plaintiff's expense, the latter never actually having borne the burden of the tax. Finally, Mason C.J. agreed with a line of American cases ${ }^{98}$ supporting the proposition that where the plaintiff had passed on the cost of the tax - the burden of which it had initially borne - to third parties in such a manner that it had been understood by the latter that the amount would be applied in payment of a tax ${ }^{99}$ then the plaintiff could be found to have been a constructive trustee of the amounts. ${ }^{100}$

Second, Royal Insurance is important because, although that case did not involve taxes that had been unlawfully levied pursuant to an unconstitutional or invalid enactment, Mason C.J. addressed the "fiscal chaos" rule discussed by La Forest J. in Air Canada. The Chief Justice seemed unconvinced that this "vague and amorphous" defence should form part of the law of Australia. He expressed his preference for Wilson J.'s "compelling" reasoning in her dissenting reasons in Air Canada. ${ }^{101}$ "The remedy for disruption of public finances," he wrote, "lies in the hands of the legislature."

\section{The adoption of THe Woolmich ${ }^{103}$ Principle in England}

Woolwich, a major building society, sought the restitution of interest on sums it had recovered from the Revenue after these sums were held to have been unlawfully levied. The unlawfulness resulted from the invalidity of the regulations upon which the levies were based. The Revenue had reimbursed the capital as well as part of the accrued interest as a matter of grace. Woolwich's entitlement to these sums depended on whether it had a right at common law to recover the taxes at issue. Woolwich had always contended that the underlying regulations were invalid but had nonetheless agreed to pay the taxes under protest. The building society had thus not paid the taxes under a mistake and this is why the Woolwich case, unlike Air Canada and Royal Insurance, was not primarily concerned with the mistake of law rule. Woolwich's main argument was that unlawfully levied taxes were, as a general rule and irrespective of whether the impugned payments had been made

Royal Insurance, supra note 89 at 74.

Supra note 68 at 1157.

Learned Hand J.'s dissent in 123 East Fiffy-Fourth Street v. United States, 157 F.2d 68 (2d Cir. 1946), adopted in Decorative Carpets v. State Board of Equalization, 373 P.2d 637 (S.C. Calif. 1962).

Such a situation arises where the plaintiff has passed on the cost of the tax to its customers by specifying in the contractual terms that a portion of the price paid by the customers was in payment of a tax imposed on the plaintiff. This was the situation in the two American cases cited $i b i d$.

There are similar suggestions in Mutual Pools \& Staff Pty v. Commonwealth (1994), 179 C.L.R. 155 , but the question has yet to be fully resolved by the High Court. See Mason \& Carter, supra note 4 at 780-81. The suggestion also appears in Brennan J.'s reasons in Royal Insurance, supra note 89 at 90 .

Royal Insurance, ibid. at 68.

Ibid.

Supra note 20. 
under a mistake, recoverable at common law. Other alternative arguments were put forward by the building society, including that its claim should succeed on the ground of compulsion.

Their Lordships unanimously found that Woolwich's primary argument could not be supported by existing authorities. However, their Lordships were visibly sympathetic to the building society's position, given the fundamentally unfair stance adopted by the Revenue which, as Lord Goff wrote, was all the more shocking given that it "benefited from a massive interest-free loan as the fruit of its illegal action." ${ }^{104}$ However, despite their sympathy to the claimant's position, their Lordships were divided (three to two) on the issue of whether it was appropriate for the judiciary to reform the law as proposed by Woolwich and to create a new, judge-made, restitutionary category pertaining to unlawfully levied taxes. The majority decided that it was ${ }^{105}$; Woolwich stands for the proposition that "money paid by a citizen to a public authority in the form of taxes or other levies paid pursuant to an ultra vires demand by the public authority is prima facie recoverable by the citizen as of right." 106

Their Lordships identified several reasons justifying the law's recognition of a prima facie right to recover unlawfully levied taxes. To Lord Goff, the fact that the common law did not provide for a general rule of recoverability of unlawfully levied taxes was, in addition to being blatantly unfair, difficult to reconcile with the fundamental principle, enshrined in the Bill of Rights, that taxes ought not be levied without the authority of Parliament. ${ }^{107}$ Second, his Lordship alluded to the particular position that taxpayers are in vis-à-vis public authorities:

... when the Revenue makes a demand for tax, that demand is implicitly backed by the coercive powers of the State and may well entail (as in the present case) unpleasant economic and social consequences if the taxpayer does not pay. In any event, it seems strange to penalise the good citizen, whose natural instinct is to trust the revenue and pay taxes when they are demanded of him. ${ }^{108}$

Ibid. at 172. Lord Jauncey, who dissented in the result, ibid. at 194-95, stated that he had not reached his conclusion without regrets: "The revenue obtained a huge sum of money which they had no right to demand and they are now hanging on to a very large amount of interest which they have no moral right to retain."

Woolwich is a most interesting decision on the fine line between acceptable and unacceptable lawmaking by the judiciary. It is interesting to compare the majority's stance with the (more conservative) approach adopted by the House of Lords in Murphy v. Brentwood D.C., [1991] A.C. 398.

Woolwich, supra note 20 at 177; see Wells, supra note 81 at 197 ff. While Woolwich concerned sums which had been levied on the basis of regulations subsequently found to be invalid, both Lord Goff and Lord Slynn - while specifically refraining from deciding whether the principle would operate in cases of misinterpretation or misapplication of a regulatory or legislative provision - indicated that they would be inclined to find that it does: Woolwich, ibid. at 177 and 205. British Steel plc v. Customs and Excise Commissioners, [1997] 2 All E.R. 366 (C.A.) supports the proposition that it ought to operate in such a context. Woolwich, ibid. at 172.

Ibid. Lord Goff was careful to point out that the Woolwich principle ought not be viewed as a type of compulsion claim, but rather a basis of recovery independent from both mistake and compulsion (ibid.). 
Lord Browne-Wilkinson and Lord Slynn agreed with the reasons invoked by Lord Goff in separate speeches. Lord Browne-Wilkinson, looking at the problem through the prism of unjust enrichment, stated that the doctrine suggested that the law should provide for a general prima facie right to recover unlawfully levied taxes. ${ }^{109}$ His Lordship justified his reasoning and conclusion by reference to the "implied coercion" faced by all taxpayers requested to respond to demands for payments by public authorities. ${ }^{110}$ His Lordship also took into account the absence of consideration which characterizes payments made pursuant to an ultra vires demand and the fact that the Revenue had, at the end of the day, no legal entitlement to the disputed sums. " "Lord Slynn's speech essentially focused on the "implied coercion" justification. ${ }^{112}$

Like Air Canada and Royal Insurance, Woolwich is also important for the significant dicta, in this case made by Lord Goff, with respect to potential limitations to the recoverability of unlawfuly levied taxes. His Lordship acknowledged that it was widely accepted that some limits had to be placed on the recoverability of unlawfully levied taxes and that the common defences to restitutionary claims might not sufficiently answer the problem's distinctive policy. Lord Goff also expressed his preference for Wilson J.'s reasons insofar as they related to the "fiscal chaos" defence contemplated by La Forest J. in Air Canada. ${ }^{113}$ Although his Lordship refused to take a definitive stance on the issue, these remarks are likely to carry much weight given Lord Goff's immense influence on the law of restitution. Finally, his Lordship mentioned the possibility that passing on might be a defence to claims for unlawfully levied taxes, but refused to express any opinion on the matter. ${ }^{114}$

\section{Comparative Analysis of the Developments in CANAda, Australia, AND ENGLAND}

\section{A. Facilitating the Recovery of Unlawfully levied Taxes: THE APPROACHES COMPARED}

In Canada and Australia, the recovery of unlawfully levied taxes has been facilitated by the abandonment of the infamous mistake of law rule. In England, the House of Lords' response to the call for reform was the adoption of the Woolwich principle pursuant to which taxes levied as a result of an ultra vires demand are, without regard to mistake and compulsion, ${ }^{115}$ prima facie recoverable at common law. What can we learn from a comparative analysis of these different approaches?

$\begin{array}{ll}109 & \text { lbid. at } 197 . \\ 110 & \text { lbid. at 197-98. } \\ \text { III } & \text { lbid. } \\ 112 & \text { lbid. at 199. } \\ \text { 113 } & \text { lbid. at 176. } \\ 114 & \text { lbid. at 177-78. }\end{array}$

iis The distinctiveness of the Woolwich principle, i.e. the fact that it constitutes a new, distinct restitutionary category, is acknowledged by Goff \& Jones, in the most recent edition of their treatise: supra note 6 at $676 \mathrm{ff}$. See also Mason \& Carter, supra note 4 at c. 20. 
First, the Woolwich principle provides a more comprehensive (and undoubtedly more satisfactory) solution to the problem of unlawfully levied taxes. Essentially what gives rise to a right to recover unlawfully levied taxes in England is the absence of any proper legal justification for the demand in response to which taxpayers have conferred a benefit on public authorities. As Lord Browne-Wilkinson pointed out in his speech in Woolwich, "[t]here is ... a close analogy to the right to recover money paid under a contract the consideration for which has wholly failed." 16 In other words, the crux of the Woolwich principle is that restitution depends on a finding that the defendant public authorities had no legal entitlement to the taxes the payments of which were made by the plaintiffs. It is true that Woolwich leaves many very important questions unanswered ${ }^{117}$ : it is unclear from the majority's reasons whether the Woolwich principle also covers licence fees, tolls, or other exactions; whether the application of the principle is limited to circumstances where payment of the impugned sums were made pursuant to a demand on the part of public authorities. Does the Woolwich principle apply in cases where the unlawfulness results from misinterpretation or misapplication of regulatory or legislative provisions which are otherwise valid?" ${ }^{18}$ What constitutes "public authorities" and does the principle extend to private entities subject to some measure of state control? What defences are available to public authorities? ${ }^{119}$ But despite these inevitable uncertainties, there is no doubt that the careful consideration by the House of Lords of the distinctiveness of restitutionary claims for unlawfully levied taxes led to the adoption of a solution which, at the end of the day, places English taxpayers in a much more favourable position than Canadian and Australian taxpayers.

Indeed, the abandonment of the Bilbie rule in Canada and Australia has not fundamentally transformed the basis upon which unlawfully levied taxes may be recovered. In these jurisdictions, recoverability is still dependent on a finding that the impugned payments were made under a mistake (of fact or of law) or under compulsion. This has important consequences for the remedies available to unlawfully deprived taxpayers, because a finding by a Court that the public authorities had no legal entitlement to disputed taxes does not in itself give rise to a right to restitution. As the law currently stands in Canada and Australia, taxpayers have the additional burden of establishing a causative mistake, or that payment occurred under compulsion, for a restitutionary claim for unlawfully levied taxes to succeed. But perhaps more importantly, the mere abandonment of the mistake of law rule provides little relief to taxpayers seeking to recover unlawfully levied taxes that were not paid to public authorities under either a mistake or compulsion. This was exactly the plaintiff's situation in Woolwich. The building society had positively responded to the public authorities' demand, primarily for commercial reasons, while maintaining from the outset that in its view the Revenue had no entitlement to the impugned sums and that it would challenge the validity of the regulations upon which the request for payment was based. The fact that a taxpayer in Woolwich's situation would not, under the rules currently applicable in Canada and

Woolwich, supra note 20 at 197.

For an in-depth analysis, see Beatson, supra note 4. See also: McKendrick, supra note 20; Goff \& Jones, supra note 6 at $680 \mathrm{ff}$.

See supra note 106.

I consider below two such potential defences, "fiscal chaos" and "passing on." 
Australia, be entitled to restitution illustrates why the Woolwich principle provides a more comprehensive solution to the problem of unlawfully levied taxes. The abandonment of the mistake of law rule is thus undoubtedly a step in the right direction, but can only be regarded as a partial (thus imperfect) solution to the problem.

A comparative analysis of, on the one hand, Woolwich, and, on the other, Royal Insurance and La Forest's reasons in Air Canada, further reveals that the reason why the Supreme Court of Canada and the High Court of Australia adopted only partly satisfactory solutions to the problem of unlawfully levied taxes may lie in the fact that the distinctiveness of restitutionary claims for unlawfully levied taxes was not central to their reasoning. ${ }^{120}$ By mainly focusing their analyses on the issue of whether the Bilbie rule ought to survive in their respective jurisdiction, the Supreme Court of Canada and the High Court of Australia have not given thorough attention to the distinctive policy considerations ${ }^{121}$ which were relied upon by the House of Lords in Woolwich in support of a reform of the traditional common law rules governing the recoverability of unlawfully levied taxes that went beyond the mere abandonment of the mistake of law rule. The Supreme Court of Canada and the High Court of Australia should not necessarily be criticized for the approach that they have adopted, as it was not strictly speaking necessary for either Court in Air Canada or Royal Insurance to reconsider the traditional rules beyond what was necessary to reach a final determination of the plaintiffs' entitlement to the disputed sums. As in both cases they had been paid under a mistake of law, a conclusion that the Bilbie rule ought to be abandoned was sufficient to determine that the restitutionary claims at issue were prima facie well-founded. Therefore, the recent developments in Canada and Australia should not be interpreted as foreclosing further developments which will hopefully lead to the adoption of the Woolwich principle in these jurisdictions.

Finally, a comparative analysis of the judicial developments in Canada, Australia, and England reveals how little reliance was placed by the majority of the House of Lords in Woolwich on the emerging principle of unjust enrichment. While in Canada and Australia, the recognition of the principle was a major factor behind the abandonment of the Bilbie rule, ${ }^{122}$ it is noteworthy that only Lord Browne-Wilkinson referred to the doctrine of

That is not to say that the distinctiveness of such claims was completely ignored by the Supreme Court of Canada and the High Court of Australia; see: La Forest J.'s reasons in Air Canada, supra note 36 at 1206 (briefly dismissing Professor Birks' Bill of Rights argument); Mason C.J.'s reasons in Royal Insurance, supra note 89 at 68 . As was pointed out in footnote 71, Wilson J., in Air Canada, supra note 36 at 1214-15, was very much conscious of the policy considerations unique to restitutionary claims for unlawfully levied taxes.

These policy considerations were discussed earlier in this article, in the closing paragraphs of section II.B.

In his dissenting opinion in Nepean, (later to be adopted by the Court insofar as it relates to the mistake of law rule in Air Canada, and Canadian Pacific) Dickson J. (as he then was) singled out the emergence of the doctrine of unjust enrichment as "the most significant judicial development in the area of mistake of law: Once a doctrine of unjust enrichment is recognized, the distinction as to mistake of law and mistake of fact becomes simply meaningless" (supra note 32 at 367-68). See also David Securities, supra note 36 at 375, 388-93. 
unjust enrichment in his speech. ${ }^{123} \mathrm{He}$ was of the view that "[a]lthough as yet there is in English law no general rule giving the plaintiff a right of recovery from a defendant who has been unjustly enriched at the plaintiff's expense, the concept of unjust enrichment lies at the heart of all the individual instances in which the law does give a right of recovery." Woolwich was, after all, a perfect example of a case where the recognition of the doctrine of unjust enrichment could have served as an important justification for reform. Lord Browne-Wilkinson's comments, coupled with Lord Goff's and Lord Slynn's failure to include in their speeches any substantive discussion of the principle of unjust enrichment and its impact on the law of restitution as a whole, suggests that the House of Lords may be more prudent than the Supreme Court of Canada or the High Court of Australia in invoking the principle to justify reforms in the law of restitution. Also, the House of Lords may not be ready to afford to this doctrine a place in the law of restitution as substantial as the Supreme Court of Canada may have after its decision in Peel. $^{124}$

\section{B. The "Fiscal ChaOs" and "Passing-ON" Defences: Conflicting Positions Compared}

\section{1. "Fiscal ChaOs": A DOCTRINE CONDEMNED}

The fear that allowing for a general right to recover unlawfully levied taxes may, in certain circumstances, severely disrupt public finances is legitimate and serious. ${ }^{125}$ An American precedent is often cited to illustrate that astronomical sums may, at times, be at issue. ${ }^{126}$ However, the "fiscal chaos" rule proposed by La Forest J. in Air Canada as a bar to the recovery of taxes levied on the basis of legislation subsequently found to be unconstitutional (except in exceptional cases ${ }^{127}$ ) has been extensively criticized. ${ }^{128}$ The

This is significant because Woolwich, was decided shortly after the House recognized, in Lipkin Gorman, supra note 13, that the principle of unjust enrichment formed part of the law of England and after the important decision of the Supreme Court of Canada in Peel, supra note 7.

lbid.

125 The importance of the problem has been widely acknowledged in recent literature: "Restitution from Public Authorities," supra note 45 at 204; "Restitution from the Executive," supra note 45 at 195ff.; Comish, supra note 62 at 52; U.K. Law Commission, supra note 4 at 102, 124ff.; McCamus, supra note 38 at 256-58; Collins, supra note 46 at 435-37; Burrows, supra note 62 at 57ff.; Mason \& Carter, supra note 4 at $774 \mathrm{ff}$; Wells, supra note 84 at $200 \mathrm{ff}$.

In United States v. Butler, 297 U.S. I (1936), the Supreme Court's decision to strike down certain taxing provisions as violating the Constitution opened the way to claims totalling almost one billion dollars and led to a crisis which was later resolved by the enactment of a statute providing that only claimants who could demonstrate that they had actually borne the burden of the tax were entitled to restitution. That statute, the constitutional validity of which would be doubtful in Australia or Canada, was later held not to violate the American Constitution: Anniston Manufacturing Co. v. Davis, 301 U.S. 337 (1937). See O.P. Field, "Prohibiting Refunds of Unconstitutional Taxes" (1937) U. Chi. L. Rev. 322.

La Forest J. held that the rule would not apply "where the relationship between the state and a particular taxpayer resulting in the collection of the tax are unjust or oppressive in the circumstances": Air Canada, supra note 36 at 1206-207. 
developments that have occurred in Australia and England are in that regard very significant, as the fact that Mason C.J. and Lord Goff have added their influential voices to the criticism of the proposed "fiscal chaos" defence casts much doubt about whether it will ever become law not only in their respective jurisdictions, but in Canada as well.

The debate essentially involves determining whether it is for courts, rather than legislatures, to address concerns that may arise in cases where the extent of the State's exposure raises legitimate fears that public finances may be disrupted to an unacceptable extent if the restitutionary claims at issue were allowed. While there is some support in the literature for the former view, ${ }^{129}$ most commentators have taken the position that the common law ought not to provide for exceptions to the recoverability of unlawfully levied taxes based on "fiscal chaos" concerns. ${ }^{130}$ Powerful objections were voiced to limitations to restitution in "exceptional circumstances" on the basis that they would very likely prove overly difficult to apply. ${ }^{131}$ But more importantly, considerations relating to the need to confine public authorities to within the legal limits of their powers are rightly viewed as outweighing public interest concerns regarding the stability of public finances. ${ }^{132}$ As Wilson J. pointed out in Air Canada, governments do, after all, have the necessary means to effectively protect themselves from financial crises through appropriate legislative mechanisms. ${ }^{133}$

While the approach adopted by His Lordship does not find much support in recent academic literature and has been openly criticized by Lord Goff in Woolwich and Mason C.J. in Royal Insurance, ${ }^{134}$ the rule proposed by La Forest J. - pursuant to which restitution will not be allowed (save in exceptional circumstances) where taxes were levied pursuant to unconstitutional legislation - is itself problematic. The "fiscal chaos" defence is questionable firstly because the distinction made between taxes levied pursuant to unconstitutional legislation and taxes levied pursuant to the incorrect application of fiscal legislation is not entirely satisfactory. As Professor Birks has written, "there is no perfect correlation between, on the one hand, the line between tolerable and intolerable fiscal disruption and, on the other, the line between invalid legislation and legislation incorrectly

supra note 89 at 68 .

Some commentators have argued that it would be appropriate for Courts to design limitations to the right of taxpayers to recover unlawfully levied taxes: "Restitution from Public Authorities," supra note 45 (Professor Birks later changed his opinion: "Restitution from the Executive," supra note 45); see also McCamus, supra note 38 at 257.

A majority of commentators have taken the position that it would be more appropriate to let legislatures address these concerns. See "Restitution from the Executive," ibid. at 195ff.; Burrows, supra note 62 at 58; Collins, supra note 46 at 436-37; Cornish, supra note 62 at 52.

This was the main reason that led the Law Commission of England to the conclusion that it should not adopt it: U.K. Law Commission, supra note 4 at 126-27.

132 Birks, "Restitution from the Executive," supra note 45 at 164 changed his opinion for, broadly speaking, that reason, adopting Professor Cornish's criticism of his earlier position expressed in "Restitution from Public Authorities," supra note 45: Cornish, supra note 62. Maddaugh \& McCamus (supra note 6) point out (at 275) that a rule barring recovery in cases of unconstitutional statutes was dubious policy since "the more severe the legislator's error, the less likely that the taxpayer will recover." The criticism can be extended to cases of misinterpretation of an otherwise valid statute. Supra note 36 at 1215; see also "Restitution from the Executive," ibid. at $195 \mathrm{ff}$. 
applied." ${ }^{135}$ It is not difficult to think of examples where fiscal disruption resulting from restitutionary liability arising from incorrectly applied legislation would be just as, or even more severe, than that resulting from the unconstitutionality of another legislative scheme.

Another troubling aspect of the rule proposed by La Forest J. is that there is little justification for non-recoverability to be the rule and recoverability a mere exception, where taxes have been levied pursuant to unconstitutional legislation. As the rule is designed, many taxpayers will have no remedy even in cases where there is no legitimate risk of unacceptable disruption of public finances. In my opinion, it fails to strike an adequate balance between, on the one hand, the necessity of avoiding that public finances be unduly disrupted and, on the other, the necessity of keeping governments within the legal limits of their powers. The importance of this latter consideration would justify, in my view, that any limitation to the right of taxpayers to recover unlawfully levied taxes be at least restricted so as to operate only in cases where there is a real risk, supported by evidence, that public finances may be unacceptably disrupted.

\section{2. "PASSING ON": DOES LosS MATTER?}

A comparative analysis of La Forest J.'s reasons in Air Canada and the High Court's position with respect to whether the so-called "passing on" defence ${ }^{136}$ should operate to defeat a claim in restitution for unlawfully levied taxes reveals profound and fundamental differences of opinion regarding the object and function of the law of restitution. ${ }^{137}$ In essence, La Forest $\mathrm{J}$. was of the view that since the airlines had recouped the loss that they had originally incurred by subsequently passing the burden of the impugned taxes onto their customers, they had in reality suffered no loss. British Columbia's enrichment could thus not be viewed as having occurred at the expense of the plaintiff airlines. "The law of restitution, his Lordship wrote, is not intended to provide windfalls to plaintiffs who have suffered no loss." 138

In Australia, "passing on" has been rejected ${ }^{139}$ as a defence to restitutionary claims primarily on the basis that the relevant consideration is not whether the plaintiff has succeeded at reducing his or her loss in dealing with third parties, but rather whether the defendant's enrichment occurred "by doing wrong to" or "by subtraction from" the plaintiff. ${ }^{140}$ The Australian approach to the problem was well summarized by Mason C.J. in the following extract of his reasons in Royal Insurance:

"Restitution from the Executive," supra note 45 at 197.

See, generally, Michell, supra note 82; Jones, supra note 31 at 28ff.; W.J. Woodward Jr., "Passing On the Right to Restitution" (1985) 39 U. of Miami L. Rev. 873; Attorney-General Mancini's opinion in Amministrazione delle Finanze dello Stato v. San Giorgo SpA, [1985] 2 C.M.L.R. 658 (E.C.J.) at 664.

However, the situation of a plaintiff acting as a mere collecting agent on behalf of a third party seems less contentious, as the unanimous conclusion reached by the Supreme Court of Canada in Canadian Pacific - to the effect that no restitutionary claim would lie - illustrates. See also Mason C.J.'s reasons in Royal Insurance, supra note 89 at 73.

Air Canada, supra note 36 at 1202.

Royal Insurance, supra note 89, which was discussed in section III.B.

Ibid. at 73. 
Restitutionary relief, as it has developed to this point in our law, does not seek to provide compensation for loss. Instead, it operates to restore to the plaintiff what has been transferred from the plaintiff to the defendant whereby the defendant has been unjustly enriched. As in the action for money had and received, the defendant comes under an obligation to account to the plaintiff for money which the defendant has received for the use of the plaintiff. The subtraction from the plaintiff's wealth enables one to say that the defendant's unjust enrichment has been "at the expense of the plaintiff", notwithstanding that the plaintiff may recoup the outgoing by means of transactions with third parties. ${ }^{141}$

The Supreme Court of Canada's reasoning in Air Canada is indeed at odds with traditional restitutionary doctrine, and the High Court of Australia's rejection of the "passing on" defence highlights an important weakness in the Canadian position. As Goff \& Jones observe in their influential treatise, the object of restitutionary claims is "the benefit, the enrichment gained by the defendant at the plaintiff's expense, it is not one for loss suffered." 142 Determining whether the enrichment at issue has occurred at the plaintiff's expense by reference to the loss he or she has actually suffered distorts the analysis by giving weight to a consideration which is fundamentally foreign to the law of restitution. ${ }^{143}$

Unfortunately, this point has been ignored by appellate courts in three Canadian provinces, which have in recent years accepted as law the "passing on" defence. These decisions have overlooked the inconsistency of this defence, which, as I have mentioned, has not yet clearly been given majority support by the Supreme Court of Canada. In Allied Air Conditioning, ${ }^{144}$ the British Columbia Court of Appeal dismissed a claim for the restitution of taxes which had been paid to public authorities under the mistaken belief that they were owed, on the basis that the plaintiff had passed on the burden of the levies to its customers. The Court rejected an argument to the effect that La Forest J.'s obiter remarks in Air Canada and the Supreme Court of Canada's decision in Canadian Pacific supported the proposition that passing on was only a defence in cases where the cost of the tax had been specifically itemized in the transactions involving third parties. ${ }^{145}$ The "passing on" defence was also accepted as law by the Nova Scotia Court of Appeal ${ }^{146}$

Ibid. at 75 [footnote omitted].

Goff \& Jones, supra note 6 at 16 [emphasis added].

See, further, Michell, supra note 82 at 154-55; Beatson, supra note 89 at 378.

Allied Air Conditioning v. The Queen (1994), 109 D.L.R.(4th) 463 (B.C.C.A.) [hereinafter Allied Air].

Such was the trial judge's understanding of La Forest J.'s obiter dicta in Air Canada and the Supreme Court of Canada's decision in Canadian Pacific; the trial decision is reported at (1993), 76 B.C.L.R. (2d) 218 (S.C.). In that case the trial judge seems to have disregarded the important distinction between the situation of the plaintiff in Allied and that of the plaintiff airlines in Canadian Pacific. In that latter case, the plaintiff airlines were acting as a mere collecting agent on behalf of the public authorities: see La Forest J.'s reasons, supra note 68 at 1157 and Wilson J.'s reasons, ibid. at 1158. The airlines were not taxpayers per se and had never assumed the burden of the impugned levies - and the Court was unanimous in denying restitution on that basis; see Taylor J.A.'s reasons in Allied as well as my discussion supra at footnotes 83 and 137.

Cherubini Metal Works v. Nova Scotia (Attorney General) (1995), 137 N.S.R.(2d) 197 (C.A.). 
and the Ontario Court of Appeal ${ }^{147}$ in cases involving the restitution of unlawfully levied taxes paid under a mistake. In both cases the defendant's argument was dismissed, as the evidence failed to show that the impugned levies had indeed been passed on to third parties by the plaintiff. None of these Canadian cases addressed or discussed in any detail whether passing on should constitute a defence to a claim in restitution for unlawfully levied taxes. ${ }^{148}$ Meanwhile, the Court of Appeal of England has rejected the "passing on" defence, although in a case not involving unlawfully levied taxes and in which the Court specifically refrained from considering whether distinctive public policy considerations justified a different conclusion in such a context. ${ }^{149}$

\section{Conclusion}

This article has first sought to demonstrate how the recent emergence of the principle of unjust enrichment and the extensive criticism that the traditional obstacles to the recoverability of unlawfully levied taxes has attracted in recent decades have both created a climate which was favourable to the judicial reconsideration of the common law's blatantly unfair stance towards unlawfully deprived taxpayers. The developments that have occurred first in Canada and then in Australia and England were thus not entirely unexpected. I then sought to examine the relevant decisions of the Supreme Court of Canada, the High Court of Australia, and the House of Lords with a view to exposing the important differences in the approaches and solutions that have been adopted in each jurisdiction. The differences arise not only with respect to the manner in which the restitution of unlawfully levied taxes has been facilitated, but also with respect to the defences that are potentially available to public authorities faced with restitutionary claims in such a context.

A comparative analysis of these recent developments has essentially revealed, first, that the abandonment in Canada and Australia of the Bilbie rule provides only a partly satisfactory solution to the deficiencies that characterized the traditional rules governing the restitution of unlawfully levied taxes at common law. The Woolwich principle adopted by the House of Lords - allowing for the restitution of taxes levied pursuant to an ultra vires demand irrespective of mistake or compulsion - offers a more comprehensive solution, one which properly takes into account the distinctive features of restitutionary claims for unlawfully levied taxes. In my opinion, neither the Supreme Court of Canada nor the High Court of Australia have closed the door to further developments

Air Canada v. Ontario (Liquor Control Board) (1995), 126 D.L.R. (4th) 301 (Ont. C.A.). That decision was appealed to the Supreme Court of Canada (supra note 49) but the Court did not deal with the issue of passing on in its judgment.

In Allied Air, supra note 144 at 472, the Court stated that obiter dicta of the Supreme Court of Canada ought to be entitled to the "greatest respect." In doing so, the Court did not point out that passing on had only been agreed to by three of the six judges who participated in the Air Canada decision. As to the authority of obiter dicta by the Supreme Court of Canada, see the excellent essay by M. Devinat, "L'autorité des obiter dicta de la Cour suprème" (1998) 77 Can. Bar. Rev. I. 
incorporating the Woolwich principle in their respective jurisdictions, and there seems to be no compelling reason why the principle should not be adopted in Canada and Australia.

Furthermore, my comparative analysis of these recent developments has revealed that developments in Australia in England cast much doubt on the status of the "fiscal chaos" and "passing on" defences in Canada. These developments are undoubtedly welcome, as they have contributed to emphasizing the basic unfairness and inadequacy of the proposed "fiscal chaos" defence and to revealing the inconsistency of the "passing on" defence with the fundamental underpinnings of the law of restitution. This has significantly undermined the value of the Supreme Court of Canada's obiter dicta on both questions in Air Canada. It is hoped that in the future Canadian courts will re-examine in a critical manner the status of the "fiscal chaos" and "passing on" defences in light of the developments in Australia and England which this article has sought to examine. Hopefully, a majority of the Supreme Court of Canada will clearly put both defences to rest and thus allow the law of restitution to evolve in a manner which is both fairer to Canadian taxpayers and more respectful of the founding principles of this area of the common law. 